Endocrinol. Japon. 1989, 36 (3), 395-401

\title{
Regulation of Prolactin Gene Expression During Early Pregnancy in Rats
}

\author{
Hisanori OGURI*, Nobuhiko SUGANUMA*, Fumitaka KIKKAWA, \\ Yutaka ISHIHARA*, Hisao SEO**, Nobuo MATSUI** \\ AND YUTAKA TOMODA*
}

Department of Obstetrics and Gynecology, School of Medicine*, Department of Endocrinology and Metabolism, The Research Institute of Environmental Medicine** Nagoya University, Nagoya, Japan

\begin{abstract}
We have shown that administration of estrogen which increases prolactin (PRL) synthesis in the rat may be mediated by an increase in poly [adenosine diphosphate ribose (ADP-ribose)] synthesis. Present investigation was attempted to study whether poly (ADP-ribose) synthesis is involved in rat PRL gene expression during early pregnancy. Anterior pituitaries were obtained on days $0,2,4,6,8,10$ and 12 of pregnancy (group C). Another group of pregnant rats was given nicotinamide, an inhibitor of poly (ADP-ribose) synthesis twice a day intra-peritoneally from day 0 to the day of sacrifice (group N). Serum estradiol $\left(\mathrm{E}_{2}\right)$ concentration was determined by radioimmunoassay. PRL mRNA was measured by cytoplasmic dot hybridization using ${ }^{32} \mathrm{P}-1$ labeled cDNA. Poly (ADP-ribose) synthesis was assessed by incubating purified nuclei with ${ }^{14} \mathrm{C}$-nicotinamide adenine dinucleotide.

The serum concentration of $E_{2}$ increased between days 2 and 4, and on day 6 it decreased to the level of day 0 . It remained low until day 12 . No difference in the serum $E_{2}$ level was observed in groups $C$ and $N$. In group C, PRL mRNA increased from day 2 and remained high until day 8 .

In group C, poly (ADP-ribose) synthesis increased between days 2 and 4, decreased on day 6 to the level of day 0 , and thereafter gradually increased until day 10. Administration of nicotinamide abolished the increase in poly (ADP-ribose) synthesis observed in group $\mathrm{C}$ during early pregnancy. In group $\mathrm{N}$, the increase in PRL mRNA was completely suppressed.

It is suggested that the increase in PRL mRNA in early pregnancy may be mediated by increased poly (ADP-ribose) synthesis. The increase in PRL mRNA and poly (ADP-ribose) synthesis early pregnancy are felt to be caused by an increase in $\mathrm{E}_{2}$.
\end{abstract}

We as well as other investigators have shown that estrogen administration to the rat increased PRL gene transcription in the

Received February 7, 1989 anterior pituitary (Maurer, 1979, Seo et al., 1979). We have also demonstrated that increased PRL synthesis in the rat anterior pituitary caused by estrogen administration might be mediated by an increase in poly 
(ADP-ribose) synthesis (Seo et al., 1986). Poly (ADP-ribose) consists of repeated adenosine diphosphate-ribose units linked by ribosyl-ribose $\alpha-1^{\prime}, 2^{\prime}$ glycosydic bonds. When chromatin proteins are poly (ADP) ribosylated, poly (ADP) ribose is covalently attached to histone or non-histone chromosomal proteins. The attachment of poly (ADP-ribose) chromatin proteins has been shown to be involved in DNA synthesis (Colyer et al., 1973, Lehman et al., 1974), DNA repair (Hayashi et al., 1977), gene transcription (Kimura et al., 1983), and cell differentiation (Kanai et al., 1982).

Many reports on changes in serum PRL levels during pregnancy in rats have appeared. Amenomori et al. reported that during the first 3 days of pregnancy, serum PRL concentrations were higher than during the following 18 days. On the 22nd day of pregnancy serum PRL increased again (Amenomori et al., 1970). In early pregnancy serum PRL increased twice a day until day 10 of pregnancy (Bridges et al., 1983). Also, recently Latrille et al. reported that serum PRL increased on 21 st day of pregnancy (Latrille et al., 1987). Serum estrogen is increased on day 4 (early) and on days 19 and 20 (late) of pregnancy (Yoshinaga et al., 1969). It has been reported that an increase in estrogen in late pregnancy is associated with increassed PRL synthesis just prior to delivery (Nicholas et al., 1981). However, whether an estrogen increase in early pregnancy plays a role in the regulation of PRL synthesis is still unknown.

Therefore, in the present study, the relationships between poly (ADP-ribose) synthesis, PRL synthesis in the pituitary, and the serum estrogen concentration during early pregnancy in the rat were examined.

\section{Materials and Methods}

\section{(1) Animals}

Female Wistar rats, weighing 200-250 g, were housed under controlled temperature and lighting (light from 0700-1900) and supplied with water and food ad libitum.

Pregnancy was induced by placing the females with males and was confirmed by the presence of a vaginal plug on the following day. This day as designated as day 0 of pregnancy. Nicotinamide (SIGMA), an inhibitor of poly (ADP-ribose) synthesis, was dissolved in phosphate buffered saline (PBS) and administered intra-peritoneally at a dose of $150 \mathrm{mg} / \mathrm{kg}$ body weight twice daily (Kazumi et al., 1980), starting on day 0 (group $\mathrm{N}$ ). The control group was given PBS alone.

\section{(2) Collection of pituitary and serum samples}

On day $0,2,4,6,8,10$, and 12 of pregnancy, rats were sacrificed by cardiac exsanguination under ether anesthesia between $9: 00$ and 13:00 hr. 4 rats were examined from each group on each of the designated days. The anterior pituitary gland was removed and immediately placed in ice-chilled PBS. After weighing the pituitary, one half of it was used for the immediate determination of poly (ADP-ribose) synthesis. The remainder was frozen on dry ice and kept at $-80^{\circ} \mathrm{C}$ until preparation of the cytosol fraction (see below).

(3) Determination of pituitary PRL content, serum PRL and serum $E_{2}$ concentrations

Pituitary PRL content and serum PRL concentration were determined by radioimmunoassay with a kit provided by the National Pituitary Agency (U. S. A.). $E_{2}$ concentrations were determined by radioimmunoassay (RIA) using a ${ }^{125} \mathrm{I}_{-} \mathrm{E}_{2}$ kit obtained from CIS-Sorin (France).

\section{(4) Preparation of cytosol fraction and} cytoplasmic dot hybridization

A cytosol fraction of rat pituitary was prepared according to the method of White and Bancroft (1982). Each frozen rat pituitary was homogenized in $100 \mu \mathrm{l}$ of buffer containing 10 $\mathrm{mM} / 1$ EDTA ( $\mathrm{pH} 7.5$ ) and $0.5 \%$ Nonidet P-40. 
The cytosol fraction was prepared from the homogenate by centrifugation at $10,000 \mathrm{rpm}$ for $5 \mathrm{~min}$ in a microfuge (Kubota KM-15000). To the supernatant, $3 / 5$ vol $20 \times \mathrm{SSC}(3 \mathrm{M} \mathrm{NaCl}$, $0.3 \mathrm{M}$ trisodium citrate) and $2 / 5$ vol $37 \%(\mathrm{w} / \mathrm{w})$ formaldehyde were added, followed by incubation at $60^{\circ} \mathrm{C}$ for $15 \mathrm{~min}$.

Aliquotes of the treated cytosol fractions, being equivalent to $1 / 30,1 / 60$ and $1 / 120$ pituitary were diluted to $100 \mu \mathrm{l}$ with $15 \times \mathrm{SSC}$ and spotted on nylon paper (Gene Screen Plus, NEN Research Products). The RNA was hybridized with ${ }^{32}$ P-labeled PRL complementary DNA probe $\left(3.55 \times 10^{7} \mathrm{cpm}\right)$. Quantitative analysis of PRL mRNA was performed by autoradiography and densitometry as previously described (Suganuma et al., 1986). The density of the spots from the day 0 pregnancy group was assigned a value of 1 unit.

\section{(5) Determination of poly (ADP-ribose) synthesis}

Poly (ADP-ribose) synthesis was assessed according to essentially the method described by Rastl and Swetly (1978). Hemipituitaries of 4 rats in a group were homogenized in $0.15 \mathrm{ml}$ of solution A containing $0.5 \%$ Nonidet $\mathrm{P}-40$. After centrifugation at $900 \mathrm{Xg}$ for $5 \mathrm{~min}$ at $4^{\circ} \mathrm{C}$, the pellet was resuspended in the same buffer and centrifuged again. This washing procedure was repeated once more. Finally, the nuclear pellet was suspended in $0.25 \mathrm{ml}$ of Tris- $\mathrm{Hcl}(0.1$ $\mathrm{M} / 1, \mathrm{pH} 8.0), \mathrm{MgCl}_{2}(10 \mathrm{mM} / 1), \mathrm{KCl}(60 \mathrm{mM} / 1)$, $\alpha$-mercapto-ethanol $(4 \mathrm{mM} / 1)$, and $1.5 \mu \mathrm{M} / 1{ }^{14} \mathrm{C}$ NAD $(287 \mathrm{mCi} / \mathrm{mM}$, New England Nuclear), and incubated at $25^{\circ} \mathrm{C}$ for $20 \mathrm{mln}$. Following incubation, $1 \mathrm{ml}$ ice-cold TCA (10\%) was added and centrifuged. The precipitate was dissolved in NCS and the radioactivity was counted (Seo et al., 1986).

\section{Results}

\section{(1) Changes in serum $\boldsymbol{E}_{2}$ cocentration}

As shown in Fig. 1, the serum concentration of $E_{2}$ in Group $C$ increased between days 2 and $4(\mathrm{p}<0.01)$, and on day 6 it decreased to the level of day 0 . It remained low until day 12 . No differences in serum $E_{2}$ levels were observed between Groups $\mathrm{C}$ and $\mathrm{N}$.

\section{(2) Changes in PRL mRNA content.} As shown in Fig. 2, the pituitary content of PRL mRNA in Group $C$ increased gradually between days 2 and day 6 of pregnancy. On day 6 , the level was 2.31 times the value for day $0(p<0.01)$,

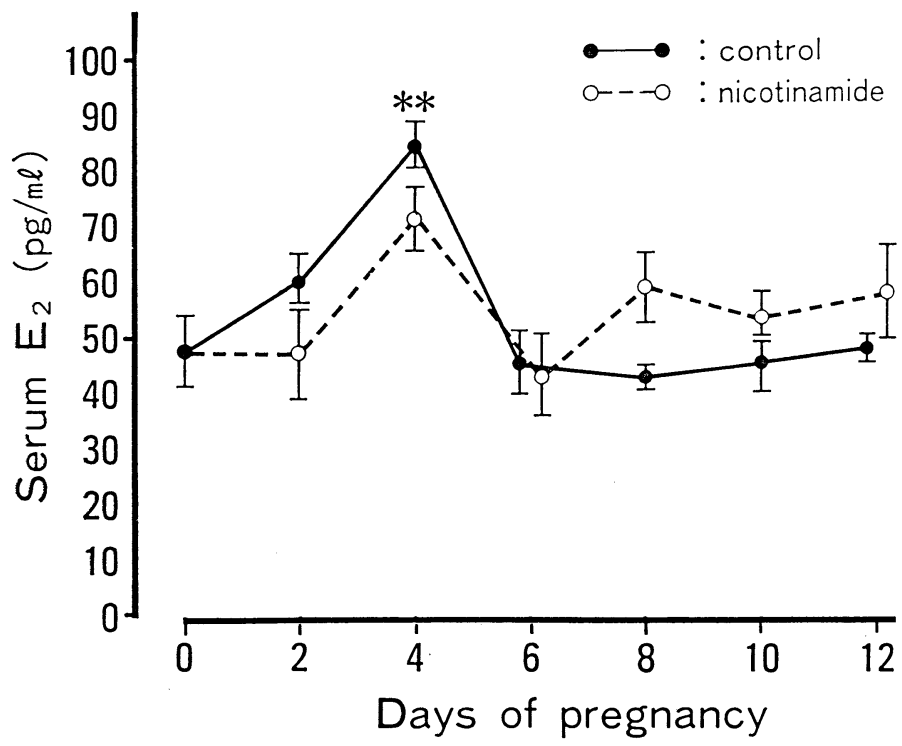

Fig. 1. Changes in serum $\mathrm{E}_{2}$ concentration and effect of nicotinamide. Compared with day 0 of pregnancy. Mean $\pm \mathrm{SE}$ are also presented. $* * \mathrm{p}<0.01$ compared with day 0 of pregnancy 


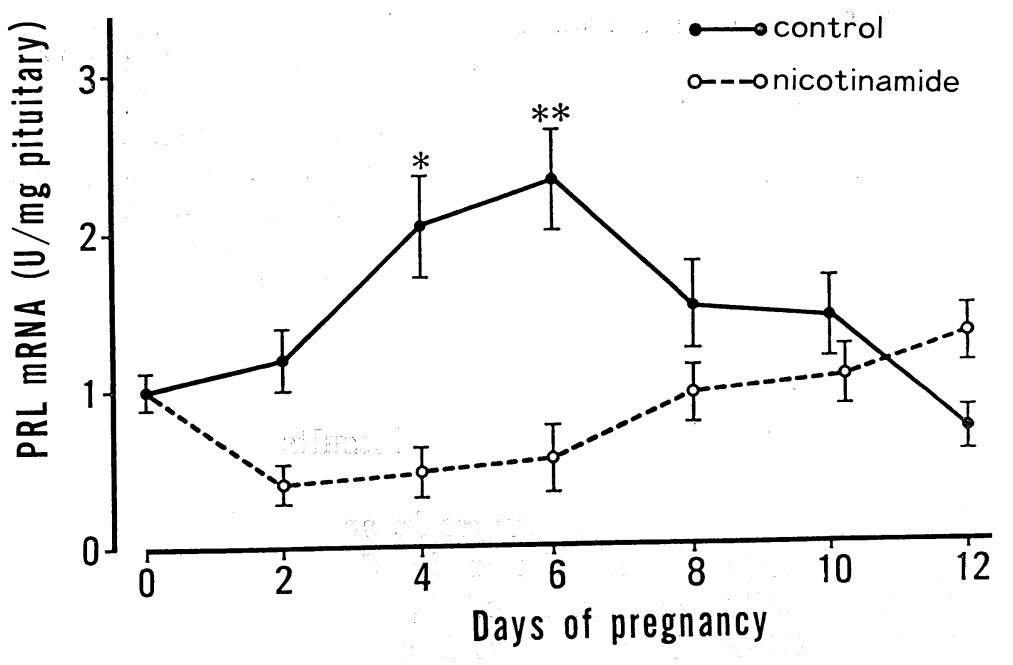

Fig. 2. Changes in PRL mRNA content Pituitary PRL mRNA was measured by cytoplasmic dot hybridization using ${ }^{32} \mathrm{P}$-labeled cDNA. Mean \pm SE are also presented.

$* \mathrm{p}<0.05$ compared with day 0 of pregnancy.

$* * \mathrm{p}<0.01 \quad$ compared with day 0 of pregnancy. and it decreased thereafter. Administration of nicotinamide completely suppressed the increase in PRL mRNA observed in Group C.

\section{(3) Changes in Poly (ADP-ribose) synthesis.}

In Group C, poly (ADP-ribose) synthesis increased between days 2 and 4, and the increase on day 4 was 1.7 times the value for day $0(\mathrm{p}<0.01)$ (Fig. 3). On day 6 , it decreased to the level for day 0 , and slightly increased again until day 10 , no significant difference was observed between days 0 and 10 . With the administration of nicotinamide, the increase in poly (ADPribose) synthesis on days 2 and 4 observed in Group $\mathrm{C}$ was abolished.

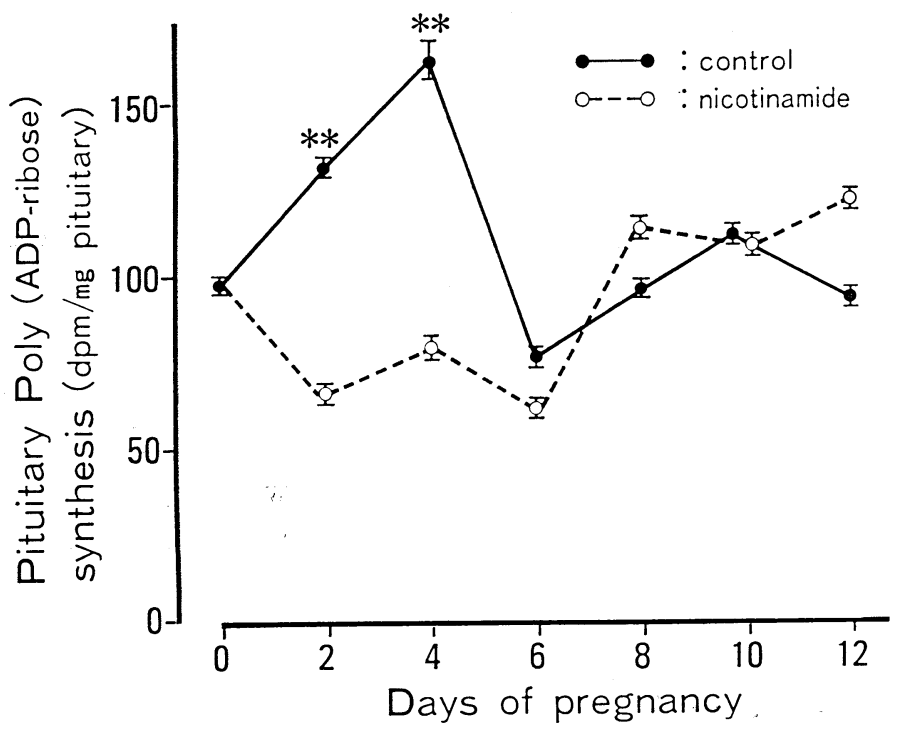

Fig. 3. Changes in poly (ADP-ribose synthesis. Poly (ADP-ribose) synthesis was assessed by the incubation of purified rat pituitary nuclei with ${ }^{14} \mathrm{C}-\mathrm{NAD}$ compared with day 0 of pregnancy. Mean $\pm S E$ are also presented.

$* * \mathrm{p}<0.01$ compared with day 0 of pregnancy. 

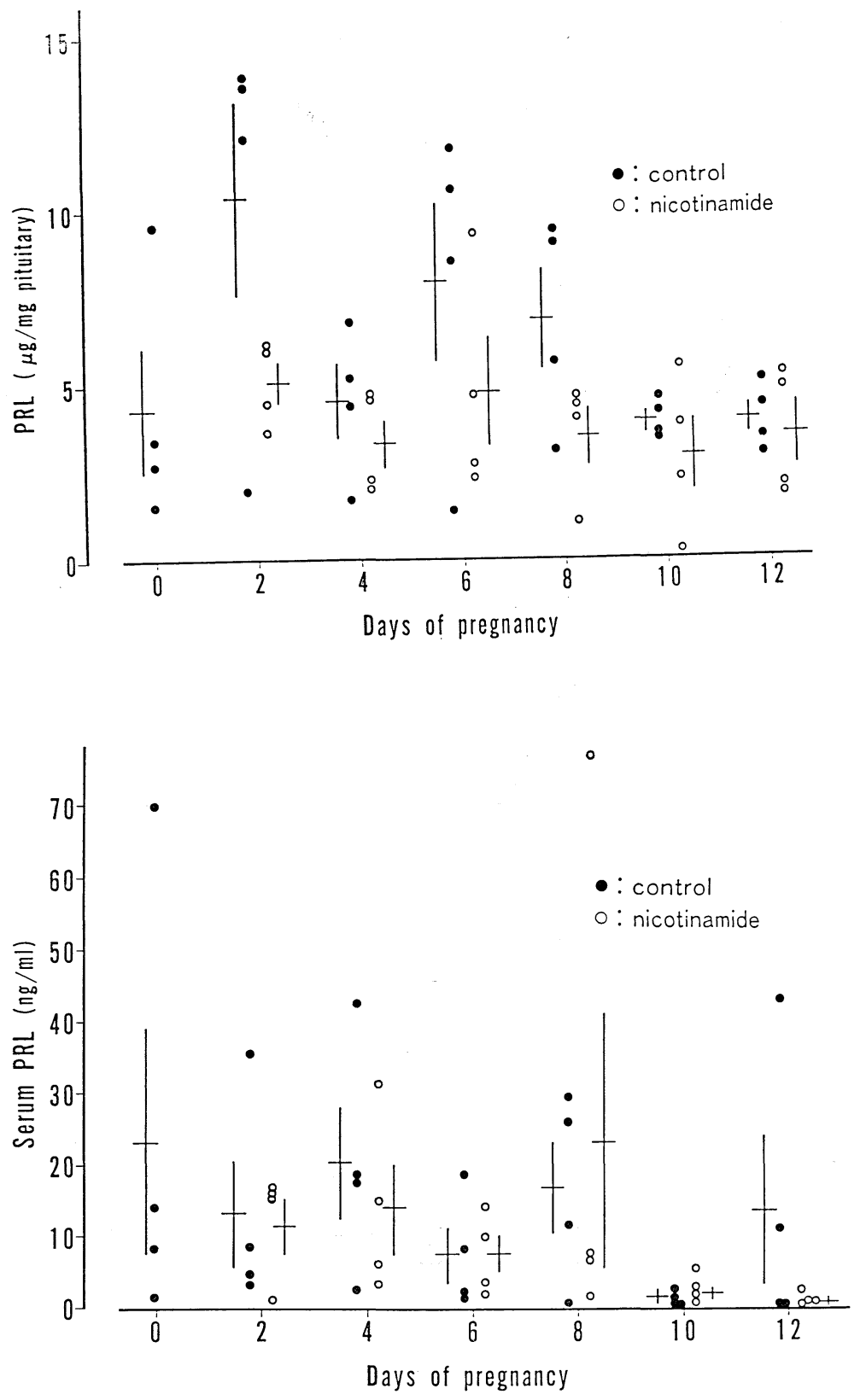

Fig. 4. Changes in pituitary PRL content. The individual values are presented together with mean $\pm S E$.
Fig. 5. Changes of serum PRL concentration and effect of nicotinamide. The individual values are presented together with mean \pm SE.

(4) Changes in pituitary PRL con- higher than that observed in Group N (Fig. tent and serum PRL concentration.

In the pituitary content of PRL there 4). Serum PRL was widely distributed each day in both groups and no significant was no significant difference between Groups $\mathrm{C}$ and $\mathrm{N}$, but in Group $\mathrm{C}$ it was slightly difference was observed between Groups C and $\mathrm{N}$ (Fig. 5). 


\section{Discussion}

We have shown in in vivo (Seo et al., 1979) and in vitro (Seo et al., 1987) studies that administration of estrogen to rats caused an increase in poly (ADP-ribose) synthesis which was followed by increased PRL mRNA. There are several reports indicating that the estrogen level increases on day 4 (early) and on days 19-20 (late) of pregnancy in rats (Yoshinaga et al., 1969). We also observed that the serum concentration of estradiol increased on day 4 and this increase was associated with an increase in PRL mRNA content in the anterior pituitary in rats.

Poly (ADP-ribose) synthesis in the anterior pituitary increased in early pregnancy in rat. The peak of poly (ADP-ribose) synthesis in the pituitary was observed on day 4 of pregnancy with a concomitant rise in PRL mRNA content. To determine if these changes in PRL mRNA were mediated by increased poly (ADP-ribose) synthesis, pregnant rats were administered nicotinamide, an inhibitor of poly (ADPribose) synthesis. The administration of nicotinamide abolished the increase in poly (ADP-ribose) synthesis and PRL mRNA observed in Group C. It was suggested that the PRL mRNA increase in early pregnancy was mediated by increased poly (ADP-ribose) synthesis. No differences were observed in the serum estrogen concentration in groups $\mathrm{C}$ and $\mathrm{N}$. From these results it is suggested that the increased PRL mRNA and poly (ADP-ribose) synthesis during early pregnancy was caused by an increase in estrogen.

There are many reports on increases in PRL synthesis during early pregnancy in rats (Amenomori et al., 1970, McKay et al., 1982). In group C, we also observed a significant increase in pituitary PRL mRNA content. Although PRL content was not significantly difference in Groups $\mathrm{C}$ and $\mathrm{N}$, there was a tendency to have higher content in Group C. In early pregnancy, PRL secretion increased twice a day (PRL surges) until day 10 of pregnancy (Bridges et al., 1983). If pituitary samples had been obtained between surges, PRL content may have been higher than our data.

We cannot explain why poly (ADP. ribose) synthesis was not suppressed by the administration of nicotinamide after day 6 of pregnancy. There was no significant difference in poly (ADP-ribose) synthesis in Groups $\mathrm{C}$ and $\mathrm{N}$ after day 6 of pregnancy. The control mechanism for poly (ADP-ribose) synthesis may differ between early and late pregnancy.

It is well known that PRL has a luteotrophic action in the early pregnant rat. When PRL synthesis and secretion are completely supressed during early pregnancy, it will cause abortion due to luteal insufficiency. Although the administration of nicotinamide abolished the increase in PRL mRNA caused by increased estradiol, no abortion was observed in Group N. Embryos were examined after day of pregnancy, but no differences in the survival rate were noted in $\mathrm{C}$ and $\mathrm{N}$ up to the last day of this experiment. Furthermore, no differences were observed in fetal weight in Groups $\mathrm{C}$ and $\mathrm{N}$ on day 12. These result may indicate that basal PRL synthesis and secretion may be sufficient for the maintenance of luteal function. The biological significance of PRL increase in early pregnancy should be still investigated.

\section{Acknowledgements}

We are indebted to Dr. J. A. Martial (University of Liege, Liege, Brussels) for the gift of rat PRL cDNA clones and to the pituitary agency for the provision of a rat PRL RIA kit. We also thank Dr. Takami Inoue for the preparation of the PRL cDNA probe. This work was supported by a Giant for Scientific Research (No. 62570750) from the Ministry of 
Education, Culture and Science, Japan.

\section{References}

Amenomori, Y., C. L. Chen and J. Meites (1970). Serum prolactin levels in rats during different reproductive states. Endocrinology 86, 506-510.

Maurer, R. A. (1979). Estrogen-induced prolactin and DNA synthesis in immature female rat pituitaries. Mol. Cell. Endocrinology 13, 291-300.

Bridges, R. S. J. Terkel and C. H. Sawyer (1983). Thyroid stimulating Hormone and prolactin secretion: Reduced sensitivity to TRH-stimulated prolactin release after midpregnancy in rats (41682). Proc. Soc. Exp. Biol. Med. 173, 527-532.

Colyer, R. A., K. E. Burdette and W. R. Kidwell (1973). Poly ADP-ribose synthesis and DNA replication in synchronized mouse L-cells. Biochem. Biophys.Res. Commun. 53, 960-966.

Hayashi, O. and K. Ueda (1977). Poly (ADPribose) and ADP-ribosylation of proteins. Ann. Rev. Biochem. 46, 95-116.

Kanai, M., M. Miwa, T. Kondo, Y. Tanaka, M. Nakayasu and T. Sugimura (1982). Involvement of poly (ADP-ribose) metabolism in induction of differentiation of HL-60 promyelocytic leukemia cells. Biochem. Biophys. Res. Commun. 105, 404-411.

Kazumi, T., G. Yoshino and S. Baba (1980). Pancreatic islet cell tumors found in rats given alloxan and nicotinamide. Endocrinol. Japan. 27 (3), 387-393.

Kimura, N., N. Kimura, G. Cathala, J. D. Baxter, and G. S. Johnson (1983). Nicotinamide and its derivatives increase growth hormone and prolactin synthesis in cultured GH3 cells : Role for ADP-ribosylation in modulating specific gene expression. DNA 2, 195-203.

Lartrille, F., J. Perraud, J. Stadler, A. M. Monro and C. H. J. Sutter (1987). Effect of ticonazole on parturition and serum levels of $17 \beta$-oestradiol, progesterone, LH and PRL in the rat. Bio-chem. Pharmac. 36, 1119-1124.

Lehman, A. R., Kirk-Bell Susan, S. Shall and W. J. D. Whish (1974). The relationship between cell growth, macrmolecular synthesis and poly ADP-ribose polymerase in lymphoid cells. Exptl. Cell Res. 83, 63-72.

McKay, D. W., C. A. Pasieaka, K. E. Moore, G. D. Riegle and K. T. Demarest (1982). Semicircadian rhythm of tuberoinfundibular dopamine neuronal activity during early pregnancy and pseudpregnancy in the rat. Neuroendocrinology 34, 229-235.

Nicholas, K. R. and P. E. Hartman (1981). Progressive changes in plasma progesterone, prolactine and corticostercid levels during late pregnancy and the initiation of lactose synthesis in the rat. Aust. J. Biol. Sci. 34, 445-454.

Rastl, E. and P. Swetly (1973). Expression of poly (adenosine diphosphate-ribose) polymerase activity in erythroleukemic mouse cells during cell cycle and erythropoietic differentiation. J. Biol. Chem. 253, 4333-4340.

Seo, H., S. Refetoff, G. Vassart and H. Brocas (1979). Comparison of primary and secondary stimulation of male rats oestradiol in terms of prolactin synthesis and mRNA accumulation in the Pituitary. Proc. Natl. Acad. Sci. USA. 76, 824-828.

Seo, N., N. Suganuma, K. Sueda and N. Matsui (1986). Estrogen induces pituitary poly (ADPribose) synthesis in the rat. in Pars Distalis of the Pituitary Gland-Structure, Function and Regulation. (Ed. by Yoshimura $F$ and Gorbman A) Elsevier Science Publishers BV.

Seo, H., K. Kanda, N. Suganuma, H. Oguri, N. Yamamoto, T. Sakurai and N. Matsui (1987). Relationship between estrogen induced prolactin gene expression and poly (ADPribose) synthesis. In Kyoto Plolactin Conference Monograph Volume 2 (Ed. by Hoshino K)

Suganuma, N., H. Seo, N. Yamamoto, F. Kikkawa, O. Narita, Y. Tomoda and N. Matsui (1986). Ontogenesis of pituitary prolactin in the human fetus. J. Clin. Endocrinol. Metab. 63, 156-161.

White, B. A. and C. Bancroft (1982). Cytoplasmic dot hybridization. Simple analysis of relative mRNA levels in multiple small cells or tissue samples. J. Biol. Chem. 257, 85698572.

Yoshinaga, K., R. A. Hawkins and J. F. Stocker (1969). Estrogen secretion by the rat ovary in Vivo during the estrous cycle and pregnancy. Endocrinology 85, 103-112. 